\title{
FATHER MAZZUCHELLI'S IOWA MISSION
}

\section{By Kenneth E. Colton}

Eminent among those who labored at the humble but not unimportant task of spreading the Christian faith on the middle western frontier of a century ago was Father Samuel Charles Mazzuchelli. For nearly thirty-four years this small, thin, ruddy-faced nervous dynamo of energy and faith served as a missionary in northern Michigan, Wisconsin, Illinois, and Iowa. Most of the facts concerning his priesthood are to be found in his popularized account of his work, written in Italian and published in Milan in 1844, Memoirs Historical and Edifying of a Missionary Apostolic. ${ }^{1}$ Although this record covers less than half of Father Mazzuchelli's active years as a priest, it fortunately covers those years of his service in the Towa portion of his mission field. But while the facts of his Iowa career are thus well known, the vibrant, personality of this earnest missionary, educator, preacher, and architect is frequently lost in either the coldness of print or in the heat of eulogy.

A scion of a well-born Milanese family, Samuel Charles Mazzuchelli was born in Milan November 4, 1807. Despite the will of his family who desired for him a secular career in polities, he entered the Dominican order of Priesthood at the age of seventeen, volunteered fior work in the mission field of North America before he was twenty-one, and on September 5,1830 , already a resident of the new world for nearly two years, he was ordained into the priesthood, before he had reached the age of twenty-three. First attached to the Mackinac mission station as a missionary to the Indians, he shortly established a church at Green Bay for the white settlers at the post, most of whom were traders. A school for the Menominee Indians was established there in 1831 with which he maintained connections during the next three years, while serving other points in the field as well. This school is significant in that it early established his interest in education,

The English version was published by the W. F. Hall Printing Company, Chicago, 1915 . 
an interest that was to be a dominant characteristic of his thirty-four years in the priesthood. Of interest in connection with his letters is his first visit to Prairie du Chien, made in September, 1832, and his first contact with the Winnebago Indians, at Portage, Wisconsin, in April, 1833. It is probable that the book about the Winnebago Indians referred to in his letters (II, V) is the one he wrote at this time, which was a translation of a catechism for Indians from the Ottawa into the Winnebago language. Prairie du Chien was again visited in Febraury, 1835. His letters concerning the Lowry mission were written a year later.

Father Mazzuchelli's association with the religious life of Iowa is included almost entirely within the span of eight years which began when he set foot in Dubuque early in 1835 , and which closed with his departure eastward with Bishop Loras, in 1843, to attend a church council at Baltimore, preparatory to sailing for his homeland, Milan, where he remained until 1845. Although it is suggested that he may have set foot in Dubuque prior to 1835 , it seems probable that his first visit to the lead mines on the western shores was not made until the early spring of 1835 , shortly before he set out on his river voyage to St. Louis, especially probable in view of his considerable activity in the previous years among the various Indian and mission points on the eastern side of the river. ${ }^{2}$ This visit brought the priest back to the lead mining regions of the upper Mississippi in July of that year, at the behest of the Catholic residents and with the consent of his church, to serve them as their missionary priest. Thus began his Iowa mission.

In 1835-1836 he was engaged in reviving the building program that gave rise to St. Raphael's at Dubuque, the corner stone of which was laid August 15, 1835, although the building itself was not completed until September of the following year. During these two years his time was largely shared between Dubuque and Galena.

His first visit to Davenport was made on his return trip from his second visit to his ecclesiastical superior at St. Louis, in 1836. On this return he stopped at Rock Island, and at this time he crossed over to the western shore where Antoine.

2Annals of Iowa 3rd Series, VI, 284; Memoirs, pp. 158-159. 
Le Claire was busy promoting the new town of Davenport. In April of 1837, after he had seen St. Raphael's safely completed, Father Mazzuchelli was once more in Davenport, this time at work laying the first bricks in the construction of St. Anthony's, which, finished in 1838, was not served by a regular priest until 1839, when the Rev. J .A. Pelamourges took up residence there, being one of the two priests brought back from France by Bishop Loras.

Little record of any activities in Iowa during 1838 by the Rev. Mazzuchelli are to be found (See VIII among his letters, page 315), most of his time was taken with church building in the eastern portion of his mission field, which left him but little opportunity to continue his work of organization and expansion west of the Mississippi. In the autumn of the next year, 1839, however, he paid his first visit to Burlington, where he found but twenty-seven co-religionists among a population of almost two thousand. On December 17th he celebrated the first Mass in the territorial capital in the dwelling of a "poor German family."

1840 was to be an exceedingly busy and fruitful year in the labors of this Dominican priest. One of the first communities to profit from the organizing and building efforts of Father Mazzuchelli in this year was that of the Irish immigrants at Maquoketa. Here, by means of the co-operative labor of the residents, Rev. Mazzuchelli set about the construction of a $\log$ church, the designs for which he probably drew himself in order to lessen the expense. Before the year was out the completion of St. Patrick's added one more church to those built by the priest in Iowa.

His attention, however, was not for long diverted from Burlington and the need of a church there, for, as he writes, "the very small number of Catholies there in the midst of a very large Protestant population was a powerful motive for introducing catholic worship there as speedily as possible ...." Despite some hostility towards the new project on the part of the ardent Protestants of the city, the work of building the new church, St. Paul's, had so far progressed that Father Mazzuchelli was able to persuade the Council (Senate) of the Iowa territorial legislature to rent its halls for their 1840-1841 
session, which began the first Monday in November. Heretofore the Council had shared quarters in the "Old Zion" Methodist Church with the House of Representatives, which continued to meet there. As in most all of Father Mazzuchelli's churches, plans for a school were provided for in the building of this church also, quarters being allotted to it in the basement. The first sermon in St. Paul's was preached by Father Mazzuchelli on the 22nd of November, the desk of the President of the Council being used for a pulpit. The financial load of building was immeasurably lightened when the priest succeeded in renting the halls of the church to the Council for its sixty days session, "for $\$ 500$ and other considerable profits." This together with the contributions of the church membership quickly eliminated the building debt.

A significant event for the Christian churches of territorial Iowa was the legislative act of July 31,1840 , which provided, under certain conditions, for the grant of a free lot to each Christian church in Iowa City. It is probable that the press of building St. Paul's in Burlington prevented Rev. Mazzuchelli from taking an earlier advantage of those provisions than he did, for it was not until the 19th of December that he made the journey to Iowa City. That he was not alone in seizing the opportunity presented by this legislative bounty is indicated when he writes that at the time of his arrival the Primitive Methodist, the Methodist Episcopal, the Presbyterian, and the Unitarian churches also had representatives there who likewise were anxious to deposit a guar. antee and to proceed in the construction of a $\$ 1,000$ church within the prescribed three year period. The first Catholic services in Iowa City were held by Rev. Mazzuchelli on the 20th of December, in the cabin of a Ferdinand Haberstroh, at which twenty-eight out of the thirty Catholies in the mushrooming city were present." On the succeeding day he celebrated Mass in an unfinished cabin at "Old Man's Creek," some ten miles west of Iowa City.

Although other religious sects were likewise taking advantage of the provisions of the act of 1840, Rev. Mazzuchelli was the first to succeed in dedicating a church structure, albeit.

\footnotetext{
Joseph Furhman, History of St. Mary's Church (Iowa City, 1916) p. 12.
} 
an unfinished one. ${ }^{4}$ On the 12th of July, 1841, Bishop Loras of the Dubuque Diocese officiated in the ceremonies which added the fifth church to Mazzuchelli's growing list. The customary school, as usual, was provided for in the basement. The church, however, was not completed until 1843. By that time Father Mazzuchelli had left Iowa and was on his way homeward, seeking funds in Italy for a new educational project in Wisconsin.

The omnipresence of this missionary is suggested by the fact that whereas he was in Iowa City in the last of December, 1840, claiming land sites for a new church, in January of the following year he held the first Catholic services in Bloomington (Muscatine), on the 25th day of the month, with eight communicants. Before the next two years had run their course, St. Matthias at Bloomingten and a similarly constructed church at Bellevue, St. Andrew's, became two additional churches to be credited to the efforts of the priest.

This completes the log of the missionary labors of Father Mazzuchelli in Iowa, for it is probable that following his return from Italy in 1845 he never crossed again into the mission field west of the Mississippi. A mention is made in his "Memoirs" of a preaching visit made to Charleston, Iowa Territory, in 1845, this is an error, however, since the book was published in 1844. It appears that upon his return to America in 1845 Father Mazzuchelli chose to devote himself to the raising of an educated priesthood for the furtherance of his faith, and these labors confined him almost entirely to the districts east of the Mississippi. During 1843 he had made arrangements with George W: Jones for the purchase of land owned by him at Sinsinawa Mounds, Wisconsin Territory, to be used for educational purposes. Sinsinawa College was established there in 1845-1846, which Rev. Mazzuchelli served as president until 1849 , when he established a seminary at Benton, Wisconsin, for the training of a Catholic sisterhuod, the Congregation of the Holy Rosary. Here at Benton he chose to remain during the balance of his years, finally succumbing on the 23rd day of February, 1864, to a sudden at-

4Cf. Charles Ray Aurner, Leading Events in Johnson County, Iozoa, History (Cedar Rapids 1912), I, 341; Memoirs, p. 274. 
tack of sickness contracted while attending to his parish duties.

Father Mazzuchelli's primary interests and concerns were those of his missionary work and the needs of the mission field of his church. He little cared for ecclesiastical recognition or preferments, it is said that on at least one occasion he declined consideration for a possible bishopric, believing that his true field of service was as a missionary and a teacher, choosing to leave the enmeshing toils of administrative work to others. ${ }^{5}$ The highest post he held in his church was that of Vicar General of the Dubuque Diocese, to which Bishop Loras appointed him in April, 1839.

A slight framed man who withstood the rigors of a frontier mission surprisingly well, Father Mazzuchelli by temperment appears to have been a spirited, genial friendly man. He enjoyed a wide circle of acquaintance with those in high places in the affairs of the territories of both Wisconsin and Iowa, as is indicated by his selection as chaplain for the Fourth of July celebration at Dubuque in 1836, his selection as the chaplain at the first session of the first Wisconsin territorial legislature, and his similar services for the Iowa territorial assembly. Although a personable man, his "Memoirs" nevertheless reveal him to be a firm uncompromising advocate of his faith, aggressive in all ways that would tend to promote and extend the bounds of his religion, even though, on the whole, he was tolerant of those among his contemporaries who differed fundamentally from him in doctrine.

Of the seven churches whose erection may be traced to the influence of Father Mazzuchelli, it is uncertain how many owed the designs of their completed structures to his drafting pencil. Of these seven he specifically mentions only St. Raphacl's as being of his own design, to "save expense." Since the logs eut for the ehurch at Maquoketa were hewn according to his directions, it is reasonable to assume that he likewise drew the original plans for this structure as well, for the settlers there were far more impoverished than were their Catholic brethren at Dubuque Mines. The Burlington church may also have been of his creation, since he states that

SMcmoirs, pp. xv, xvi., 
he "had the entire charge of this undertaking." As for the churches at Iowa City, Bloomington, and Bellevue, especially for the latter two, one may infer that he at least contributed substantially in the drafting of designs of the churches erected there, although an actual statement is not ventured by the priest. Conclusions as to his architectural contributions in the building of these seven churches are all in the field of probability, and rest upon both the reticence of his Memoirs and his known skill as a draftsman. It was not in the designs for churches, however, but in the organization of the church itself as a worshipping unit that Father Mazzuchelli, and the Protestant clergymen as well, made their real contributions to the state, and on this score, each of the seven churches will yield to him the inspiration of their organization.

A further point in the qucstion of Father Mazzuchelli's contributions to Iowa architecture is the often mooted point of who drew the plans for the Old Capitol at Iowa City which housed the territorial and state government from 1841 to 1857. While it may be true that the final plans according to which the building was built were not those of Father Mazzuchelli, his friendly terms with the members of the legislature, the desire on the part of all that the structure be worthy of the territory, and Father Mazzuchelli's known skill, together with his frequent visits made to Iowa City in the course of the building of St. Mary's, suggests the more probable nature of his contributions.

Many of the interests which are reflected in Father Mazzuchelli "s "Memoirs" can be traced in the letters below, written between the years 1835 and 1838 . That he was especially interested in education and "always erected a school house in connection with each of the twenty-five or more churches erected by him ...'" is given credence in his comments on education and the Winnebago mission. Education was a dominant interest throughout his life, as both his church. building and his later activities in advancing the education and training of missionaries for the church amply attest. Although he believed in education, he believed it should be under the eare of the church, in fact his efforts for education

-Annals of Iowa, 3rd Series, XIX, 444-448. 
appear to have been rooted in a conviction that education meant also a proper religious training. In this he was in complete agreement with his contemporaries, Protestant and Catholic alike.

The impulsive eagerness of Father Mazzuchelli to corrent the evils he thought he saw in the work of Dr. Lowry among the Winnebagos may well be pardoned, for in that work he saw that which ran counter to both his religious creed and his educational theories. This ardour and religious zeal, however, sometimes led him to steps that did more credit to his passionate earnestness than to his accurate appraisal of those who differed from him. In 1833 Rev. Mazzuchelli had applied to Governor George B. Porter of Michigan Territory, under whose jurisdiction the Indians then were, petitioning that the education of the Winnebagos be intrusted to his church, however, his application had arrived too late, and had to give way to that of Dr. Lowry.' Thus, in addition to differences in creed, the disappointment of being denied this opportunity may have created a mote in his eye when viewing the work of the Cumberland Missionary. The disappointment appears to have been a deep one. It is said that several efforts were made to secure the removal of Dr. Lowry from his post, although it is doubtiful if Father Mazzuchelli directly initiated them.' These efforts, in throwing him upon the good offices of representatives of the American Fur Company, placed him in something of a paradoxical situation, for the Company was never known for their disinterested regard for the welfare of the Indian. The co-operation of the Company may have been the more readily given since Dr. Lowry was at this time serving under the famed Indian agent, General Joseph M. Street, with whom the Company was constantly at serious odds.

Just what accounts for the marked antipathy of Father Mazzuchelli towards General Street is not so readily appar: ent, for in this day the General is esteemed to have been an honest and a capable friend of the Indians. It may be that there is a partial truth in the picture given by Father Mazzuchelli, however, it is not consistent with other portraits of

TIbid., XVII, 114

slbid. 
the agent." It is also equally possible that the subtle influences of his friends, H. L. Dousman and Joseph Rolette, both Company traders and nominal Catholics, and both hostile to General Street, may have enntributed to his colored estimation of the agent. Again it may be that the mote in his eye which clouded his vision of Dr. Lowry may have affected his view of others as well.

Father Mazzuchelli's interest in polities is also evident in his letters, which bear confirmation to his Memoirs for a lively interest in, and a keen observation of, the contemporary scenc. His grasp of the fundamental principles of his adopted country, and his understanding of the relationships between the federal government and the several states and territories is the more notable in view of the fact that the wandering life of a missionary affords but little opportunity for the study of such subjects.

His political sympathies, like most of his contemporaries on the western frontiers of his day, were largely personal and local, not national, for the lines of national political cleavages had not yet entered the territories bordering the Mississippi. His comments on polities to George W. Jones are those of one personally and sympathetically interested in the political future of a friend. It will be remembered that Father Mazzuchelli was probably acquainted with Jones as early as 1834 , if not before, that Jones had contributed to the building fund for St. Raphael's, and at a later time it was from .Jones that Father Mazzuchelli purchased his land sites for his Sinsinawa College. All the other three men men. tioned in his letter (II) were hostile to the Dodge party in Wisconsin, towards which the priest was friendly; at a later period he married August Casear Dodge, the son of the then governor of the territory. Father Mazzuchelli's familiarity with the operations of government doubtless owed much to his wide circle of acquaintances among the political figures of the territories of Wisconsin and Iowa; it will be remembered that he was selected chaplain of the Fourth of July celebration at Dubuque in 1836, at which time his toast was to the glory of the United States and the new Wisconsin Ter-

9Ibid., II, 82-105; III, 601-623: XVII, 105-128. 
ritory, he was chosen chaplain to open the first session of the first Wisconsin territorial assembly, and he served in a like capacity to the Iowa territorial legislature of a later date.

That Father Mazzuchelli was not without a sense of humor is suggested by his comment on the Iowa-Missouri boundary line dispute in the course of which he says that "in the United States, civil wars usually originate in the Printing Office, where also the peace is concluded, whereupon there is a sacrifice, at most, of the honor of a few citizens. Would to God that all the horrors of war might be reduced to simple typographical wars like these!"'10 In this wish and hope we all heartily share.

\section{LETTERS OF FATHER MAZZUCHEILLI}

\section{I}

Coll. Jones

Sir,

Your presenec is respeetfully requested on Sunday next, 12 July 3 $o$ 'clok P. M. at Mr. Leopold's House, where a general assembly will he held by all the Gentlemen of Galina and vicinities for the purpose of making arrangements to erect a Catholic Church.

Please to communicate the same invitation to all the inhabitants of your neighbourhood.

10th July 1835

Galina III.

Your Most ob. Servant Samuel Mazzuchelli C. Priest

James Duane Doty, 1799-1865, was a prominent political figure in both Michigan and Wisconsin territories and was later a federal office holder in Utah Territory, where he died. After suffering the defeat in 1835 referred to here by Father Mazzuchelli, for the election of the Michigan Territorial Delegate for the district west of Lake Michigan, Doty successfully opposed the Dodge faction in 1838 by defeating G. W. Jones in his campaign for re-election as Wisconsin Territorial Delegate. His eleverness and shrewdness made Doty generally suspect among many of the leaders of the territory, although he had a popular following among the people.

Hercules L. Dousman was the general agent for the American Fur Company at Prairie du Chien, Portage, and Green Bay. In 1834 he became co-partner with Joseph Rolette in

${ }^{10}$ Memoirs, p. 253. 
control of the Company, succeeding to sole control on the death of the latter in $\mathbf{1 8 4 4 .}$

Morgan L. Martin, also a prominent political figure, was a cousin of James D. Doty and opposed both his cousin and George W. Jones in the four-way election contest of 1835 which Jones won.

Thomas P. Burnett was a sub-agent at Prairie du Chien under General Street from 1829-1834, a lawyer and political power in the lead mining region of western Wisconsin. $\mathrm{He}$ was an unsuccessful contestant for a seat in the Council of the first Wisconsin Territorial Assembly on a disputed interpretation of the election laws. Following this defeat he quickly became a caustic and bitter critic of Gov. Dodge's administration in the territory. His campaign in 1838 against Jones and Doty was unsuccessful, however, it is probable that he ensured the election of Doty by drawing away votes from Jones.

Joseph Montfort Street, 1782-1840, was the U. S. Indian Agent at Prairie du Chien for the Winnebago Indians from 1827 to 1839, when he was removed to Agency City, Iowa Territory, as agent for the Sauk and Fox tribes. Although in constant difficulties with others over his conduct and management of the agency affairs, he nevertheless seems to have been honest and capable. His umrepressed whiggism in the years when that party was but a minor party in both Wisconsin and Iowa, his somewhat pompus bearing, and above all, his hostility towards the conscienceless depradations of the Company traders and others upon the annuity incomes of the Indians made him a constant center of controversy.

David Lowry, D.D., 1796-1877, was a Cumberland Presbyterian minister and missionary, teacher of such Winnebago Indian children as voluntarily availed themselves of the school provided for them by the treaty of 1832 . The mission school was first located on the Yellow River in Allamakee County, Iowa, erected in 1834 and opened in 1835; in 1840 it was moved to the Turkey River, also in Iowa. Prior to the opening of the mission in 1835, Rev. Lowry had conducted his educational work among the Winnebagos at Prairie du Chien, consequently he and Father Mazzuchelli were 
doubtless well acquainted. Iowry later followed the tribe in its removal into Minnesota in 1848, and remained with them until they moved in 1863 to South Dakota. See Wisconsin Historical Collection, Vol. XII, page 405, fn.; also Annals of Iowa, 3rd Series, Vol. XXI, page 248.

George W. Jones

Dear Friend.

9th Feb. 1836.

Prairie du Chien.

It is with the greatest pleasure that $I$ read your exertions to obtain various improvements for the new Territory. I doubt not that you will be successfull in every thing that can possibly be expected from Government. I arrived at this place few days ago. The people here do not know you. Mr. H. L. Dousman who is very well liked by all the inhabitans, and is the principal man of the Company, has, he told me, supported Doty because he knew him well and was employed by the Company. I spoke to him on your good and sincere dispositions (qualities unknown to J. Doty.) \&c. \&e. Dousman is prefectly reconciled with the election. I say this because it is necessary to be ready for a now olection. Dousman is the most influential man here and of excellent dispositions, he is besides ny good friend. Doty must be very officious [?] yet. Martin will certainly do his best. Mr. Rernett who is the jac ........... at Green bay will, in my opinion, at the first opportunity be a well supported candidate for any office. You have no support here yet To be friend of G1. Street is the same as to be very unpopular: for his character is that of a great liquorite [\%] and a thief of Government money. I would advise you now to confer [?] with inim for he will propably [probably] be envolved in great difficulties (some thousands dollars of the Wimnebagos cannot be found). Among the enemies of Street, Dousman is the first I am confident that this County may be gradually turned in your favour. Sloould the Am. Fur Company and Mr. Peter Pauquett of the Wis. Portage ask any assistance from $y \circ u$, and have their wishes satisfied, or could you do them any service, all your opponents from the Portage to the Prairie would stand in your diffence. I say all this from personal Knowledge, but I do not wish it to be known. Last summer I wrote to you about the Winnebago Schnol; near Prairie du Chien, and told you that Mr. Lowry who is the Superintendent of the same could do nothing for the indians, to day I went to see the schools (8. or 9. miles from this village) it is really disgracefull to Government it is now 18 months that the mission is opend, he has but 2 indian boys and 5 females not one pure indians, only 2 with some Winnebngo blood, the others are part Menomanee or Sioux and white, not a particle of good done, and none to be expected. that mission uses [?] Gov. .......... with indian money $\$ 4,500$. The indians refuse to give their children and ask a Priest. The agents never look for the real good of those poor ereatures; speculation is their God: so they often blind Gov. [to the facts?] It is evil and unjust to use so much of their [Indian] money to no purpose and against their 
will. Most all the inhabitans of this place are Catholics who with the rest do condemn the present condition of the school now extremly unpopular and wish Gov. to remedy the evil. Mr. Jones please do call on the President and read the letter I wrote to him in the month of May last from St. Louis, and in few lines you will be enabled to see everything, do your best to obtain justice for me [\$] and time will convince you that you have done a good deed. My intention is to have an assistant Priest in the indian school. Mr. Kane of T M. promised me last summer to do his best beforc the President himself, he knew my claims to be nothing but justice to the indians. My letter to the President was probably sent to the indian department, with the little winnebago book I printed and sent with the letter. Please sir to serve me in this matter and wish me to Galina as soon as possible.

Your Friend.

Samuel Mazzuchelli, C. P.

\section{III}

Mr. G. W. Jones.

20th Feb. 1836

Prairie du Chien

I write you few lines again for a thing that lately came to my Knowledge, and for which I' do feel much interest. G1. Street's son, Post-Master of Prairic du Chien, will shortly leave this place, so that the Office shall be vacant: I suppose that several of this place have 'already made some steps towards obtaining it. There is but few leading men here. Mr. Rolette's conduct has leaft him withont a single friend. Two or Three others are of a very little account. I see but. one whose happy disposition of mildness, justice and liberality, have and shall always secure to him the affection of every man. Mr. Hercules L. Dousman of whom I speak, does also possess a perfect Knowledge of the French language, and the ligh esteem and confidence manifested to him by the French proves his popularity. I am convinced that if there is any man here deserving an office for the good of com [m] unity, he is the one. I wish you to remark that it has been his conduct that ereated the public esteem and affection, and that $I$ do not speak throngh religious motives, for Mr. Dousman does not profess himself to be a Catholic. Shortly. I shall be about your house, and hope to see and often visit Mrs.' Jones.

$\begin{array}{ccc} & \text { Your Friend } \\ \cdots & \text { IV } & \text { Samuel Mazzuchelli, C. P. } \\ \cdots & \text { Galena, IJl: } \\ \text { - } & \text { March 26th 1836. }\end{array}$

'Fo:Mr. G. W. Jones, -. .

I am extremely pleased to see you şo much interested in whatever relates the interests of the new Territory The boundaries of the $\mathrm{L}$. of Michigan are truly [?] but I believe not injurious to the Wisconsin Terr. the Peninsula between lake Superior and lake Michi. gan on account of its. situation will be an: incumbrance to the State. I 
prefer one ........... on the west [?] of the Mississippi to one hundred on the shores of L. Superior. When I read, in your favour of the 3rd inst., removal of the Winnebagos uest of the Mississippi, I was seized with fear. The members of Congress deslike indian wars, and appropriations to such an object, but saldom or never consider the causes of them. I am convinced that most of our indian wars are the natural and unavoidable consequences of the misconduct of the whites. Most of our indian Treaties are badly planed by individuals, unfairly ratified and shamefully executed, individuals make their fortune at the expense of justice government is deceived and the indians abused. The President and the members of Congress judge from what thdy read in..........., but the indian a little wiser than we are judge from facts only $T$ say this in......... The winnebagos are unwilling to abandon that land which they sold in the year 18:2, many of them live on it yet, and I Know from their own mou'h that they will rather fight than make another treaty. Several articles of that of the year 1832, were not fulfilled by the U. S. they may go to war on that ground. I will prepare a letter on this subject by the next mail. It will be very prudent for you to be very carefull in planing a new Treaty with the winnebagos, for it may have distressfull consequences. I shall explain every thing in my next. Do not trust General Street he is a real liquorite [9] and a bad man I say this although I never spoke to him: and bc carefull not to sanction any improvement [?] for the mission house of Yellow river near Prairie du Chion, for it is a speculation and a great imposition on Gov. and Indians. Please to attend to all those things I wrote you in my last two letters. If possible, drop few lines to Bishop Rese at Detroit, he will be extrcmely pleased of your acquaintance.

I expect your family a few days The mississippi is covered with ice yet, but it looks bad.

Your Ob Sr

Samuel Mazzuchelli, C. P.

P. S. Excuse my negligence my next shall be ....t...........sable. S. M.

V

By the treaty of September 15, 1832, the Winnebagos engaged to cede their lands east of the Mississippi in return for a concession of the Neutral Ground, established by the treaty of 1830. On November 1, 1837, they ceded the eastern part of the new lands, and accepted the fact that new lands would soon have to be selected for them. In the treaty signed in October, 1847, and ratified February 4, 1848, the Winnebagos specifically relinquished all claims to the Neutral Ground and prepared to move to a reservation west of St. Peter's River, then still in Iowa Territory. 
29th March. 1836. Galena Ill.

Mr. George W. Jones.

Sir,

The intimacy now existing between us has suggested me to write you few lines on a subject now before Congress, and in which you seem to take much interest. As the delegate for the Wisconsin Terr. it devolves on you, to procure those ammiliorations in the country which may tend to the prosperity of its inhabitants; and I as one of them, cannot remain indifferent. The removal of the Winnebago indian west of the Mississippi, (could it be effected without hostilities), is now considered by Gov. a necessary step towards the security and peace of our settlements. Since the year 1832, I had the best opportunity of Knowing the character and disposition of those indians; having at difiercnt periods spent a considerable time in their villages, for the purpose of propagating among them those religious and political principles which are the foundation of human happiness. My endeavours were crowned with as good a success as I expected, and enabled me to publish a little book in the Wimnebago language, and to establish a regular school. But leaft all alone, without the least support, utterly unable to defray. my small expenses, I was compelled to abbandon the indian land and the most charitable of all undertakings. This appeared in the spring of the year 1835. It all appears from the statement of Mr. Herring that the Catholies have a school among the Winnebagos, this is not the case now; and from the same statement you bilieve that $I$, the only $C$. Priest who lived among the Win., receive an appropriation: This is not true, for I never received a cent from Gov. dircetly or indirectly. I have a great deal to say on this subject, but I shall no niore set up justice against interest, for the latter became the Gospel of the day.

The Knowledge I have of the Win. Indian, presses me to advise you as a dear friend to be extremely cautious in giving your opinion respeeting a new treaty with them. That nation has and always does, probably more than any other, harbour hostile principles against the Gov. The miserable condition to which they are reduced prevents them from proving themselves open enemies. Above all things then be just and prudent. Before you encourage a new treaty with them see whether the conditions of the old ones have been fullfiled in the part of Gor.: for now days the violation of treaties is believed a sufficient cause for war among nations. Now I shall write you what I know on this subject. The first article of the treaty made in the year 1832 at Rock Island, establishes the lines of the Winn. land west of the Wisconsin river: notwithstanding the plain expression of that article, some Gov. men pretended that those indians were by that treaty bound to emigrate west of the Mississippi. This unjust pretension gave birth to an open violation of an important stipulation of that Treaty, for there Gov. solemnly promised the Indians, in consideration of the land they ceeded to the U. S., to support 6 agriculturists, and 12 pair of oxen during 30 years, for the benefit of that nation. It is only about 18 
months that two men as far as it can be assertained are employed about the Winneb. mission house built on yellow river near Prairie du Chien, which mission has for its support a separate appropriation of $\$ 3,000$ per annum. Even in the supposition that those two men are agriculturists for the Winneb. the nation is unjustly deprived of four. As to the 2 or 3 pair of oxen and ploughs about the same mission it would be difficult to say who is the owner of them, and for whom they work, if: they work at all. Six agriculturists well employed sinee the year in spring of the year 1833 could in my estimation have reconciled the Winn. with the U. S. That article of the treaty that speaks of the Schools, shows how little the writer of it was acquainted with the indian caracter. On this head the Win. are shamfully abused: Persons ntterly incapahle to instruct them are appointed teachers, and that elass of men wished by the indians, and generally Known as to that office are by gov. entirely disregarded. Gov. maybe considered guilty of solemnly promising the indians to instruct them, and neglecting the proper means to convey instruction to them. Moreover why should their schools and other improvements be nade on the U. S. land, and at the same time wish to see the indians within their boundaries? Speculation will answer that it was so necessary to encrease property at the expense of the poor creatures, and it secmed creul to locate a wife and children far off in the indian land. By these proceedings the ohject of the school can never be effected, no wonder then if they prove .................. of the whites. You may tell the President that if private interest could be entirely destroyed the indians could in a very short tine be ammiliorated and made our friends. Reguarding the indian annuities I have nothing to say but that it is a good thing for the whites, and that some money of the year 183 ? due to the indians of Fort Win. has (?) probably lost the road from Praire du Chien to that place. Our Gov. boasts of doing a great deal for the children of the forest, the reports in the indian department are crowded with missions, improvements, civilization, teachers, school, scholars and like miracles, all this calls to mind those words of an aneient writerPartmiunt montes ct naritur ridicules mus. That is "The mountains bring forth a child and there is born a ridiculus mouce." It is my belief from what $I$ know, that at least nine tenths of the flattering reports in the indian department are nothing but the work of misers [?] to continue in secret the profitable work of speculatuion. The President and others think that the laws of the country have prevented liquor among the indians, to my Knowledge liquor and intoxication is as much common now days among them as when there was no law they have plenty of it wherever they go, provide they pay for it-I could say more than fyou would be willing to read, but I do not think it necessary. In my next I shall expose my private views respecting the most prudent and just means to be employed by Gov. to procure the indian title on our frontiers. For the present. $I$ wish you to be con vinced that the indians are not well used [?], that we take all. possible 
advantages over them without giving them the opportunity of a diffence, and that it is the duty of Gov. to redeam [?] in all these things, and do away that mean, low, vile, unjust and destestible spiritt of favouritism. What I said of the Win. I have all reasons to believe the case of all other nations about this country. Your True Friend

Samuel Mazzuchelli C. P.

Excuse all faults for I have not-read my letter over

\section{VI}

Col. S. C. Stambaugh was an Indian Agent at Green Bay from 1831-1832, and a special agent from 1832-1836.

Henry Gratiot, a leading lead miner and merchant near Galena, was particularly trusted by the Winnebago Indian: and had on several occasions served them and the government in negotiations between the two. He died sixteen days following the date of the letter below.

Joseph Rolette was an American Fur Company operator and one time partner of H. L. Dousman, born in Canada and early educated for the priesthood. A hard driving man in a bargain, he was nevertheless generous and liberal in hịs helps and his favors.

\section{April. 1836}

Galina, Ill.

Col. Jones

Sir,

In my last I have said some thing on the. Winnebago Indians which I hope did not offend you: now since you wish to Know my Ideas on the manner of instrueting the young among them and on the subject of a treaty with them I. shall write you few lines more. Respecting the best plan of educating the indians I refer you to a letter of mine sent by Col. Stambaugh from Green bay to the Indian department in the fall of the year 1831. and to a statement I made on the civilization of the Manonanees in the winter of the year 1834 and sent to the Indian department in the spring of that year by the Rt. Rev. Frederic Rese Bishop of Detroit. you may also see some thing in the letter I wrote to Genl. Jackson in May last from St. Louis. There is nothing more certain in my mind that the only efficatious manner to improve the indians is to intruct them on their own land as far as possible from the whites, and in their own language by persons who are not speculatiors, hut acting upon a consientious principle. Moreover an entire separation between them and the whites is absolutely indispensable for them and for us. I know that all these things are difficult in practice, but $I$ am convinced that they are all conditions sine qua non without which nothing can be done. Although it is a very great and undeniable truth, still it appears to some incredible, that the Catholie 
Church Only is eapable to instruct pagan nations. All indian nations in their world state have that respect and confidence in the $C$. Priests which any other class of men could never gain from them. Had predjudice been put aside and had the secular arm supported the Priests among the nations, how different would be their condition at present! But it is not proper for me to say much on this subject-

In order to effect a Treaty with the Winnebagos and remore them west of the Mississippi, the first step to be made, is to appoint some of their friends as commissioners. This $I$ should consider half of the treaty Mr. Henry Gratiot, Mr. Hercules Dousman, Mr Joseph Rolette are very proper persons for the task. Yourself and Mr Brush could be united to them. Another thing necessary to buy their land without difficulty, is not to require from them and immediate removal but to grant [8] to them of it this year and secure a good residence for them on the west of the Mississippi. do not foget that it is as difficult for an indian to ahandon his home as for a white man. It is a very great policy in indian Treaties to give them the privilege to propose the articles, many dissatisfactions could thus be prevented among the indians. T. see in the various reports of the Indian Department that every thing is represented as extremely easy, but I Know better, if the indians of rockriver will go to the Neutral Ground Those of the Wisconsin willnot. That the Manomonees are dissatisfied with all the useless improvements made by Gov. for them $I$ believe is [q] they are robed [robbed] more than any other nation; but that they wish to sell I deny it. Be always prudent, enough never to rely much on reports. Those among the Manomanees who labor, raise more than enough, and have the abundance (see $\mathrm{Mr}$ Brush; report December 14, 1835) are those whom I. and other Priests baptized and instructed, those who fre. quent the $\mathrm{C}$. Church at Green bay. Truth is never stated as it is by predjudiced and covitous men. Gov. has for 5 years supported an Episcopal mission for the Manomanee, which has done nothing more than received the money and send exagerations to Washington.

After a few days the Church of Dubuque shall be continued with the greatest rapidity and soon be finished. We want money to pay the masons. I shall take the liherty to ask Mr. Gregoire for the balance of your subscription. In a short time the sum subseribed for the Church will be intirely paid, it is a credit to the inhabitants.

Your most ob. Samuel Mazzuchelli C. P.

Mrs. Jones has not yet arrived in Galena. The season is very cool, and the streets are extremely bad.

\section{VII}

Towns in those early months were largely paper creations drafted with expectations of future profits. The legislature was consequently plagued with demands for surveying and 
special dispensations that would be beneficial to each petitioning proprietor.

For an excellent account of the contest for the location of the seat of government of Wisconsin Territory see Joseph Shafer, The Wisconsin Lead Region, State Historical Society of Wisconsin, 1932, pages 57-73.

Mr. G. W. Jones.

5th Jan. 1837 Galina

\section{Dear Sir,}

Our legislature has failed doing that for which it was formed, speculation got into it like the colera into a dissipated town. I have no refference to the question on the seat of government. I mean that they have not made a code of laws, and that the members have signed more deeds than laws. I hope that your exertions at Washington will prove as successfull this winter as they have been last. I have no favours to ask of Congress, \& should that be the case, to you I should write. Please Sir, to enquire after that letter which I mailed here last: April containing a permit of $\mathrm{Mr}$ Scheldon to Bishop Rosati to occupy a certain lot in Dubuque for church purposes. If you see that it cannot be confirmed at Washington send it back to me. After a few days I shall visit your family.

Your friend Samuel Mazzuchelli, C. P.

\section{VIII}

In March of 1838 Samuel Mazzuchelli signed a petition to the President of the United States sent by his "memorialists Citizens of Scott County (Wisconsin Terr.)" recommending the appointment of George W. Jones, then Territorial Delegate from Wisconsin Territory, as the governor of Iowa Territory, expected to be created soon.

12th Nov. 1838.

Sir, Galena

I write to you at Detroit because I suppose you at that place by the time that this letter will reach it. You will confer on me a great favour and obblige ne very much by calling on the Rt. Revd. Frederic Rese Bishop of Michigan residing at Detroit near the Cathedral. Please to present him my respects. If $I$ shall be in need of your official assistance I shall write to you.

Your Most Ob. Ser.

Samuel Mazzuchelli C. P. 
Copyright of Annals of Iowa is the property of State of Iowa, by \& through the State Historical Society of Iowa and its content may not be copied or emailed to multiple sites or posted to a listserv without the copyright holder's express written permission. However, users may print, download, or email articles for individual use. 